\title{
Research Paper Determinants of purchase probability and consumption of egg: An evidence from Indian households
}

See end of the paper for authors' affiliations

\section{Correspondence to :}

\section{UMANATH}

Department of Agricultural Economics, Tamil Nadu Agricultural University, COIMBATORE (T.N.) INDIA

Email:

umanatheconomics@ gmail.com

\section{Paper History :}

Received : 28.01.2016;

Revised : 17.02.2016;

Accepted : 24.02.2016

\section{UMANATH, R. PARAMASIVAM, V. KAVITHA AND T. THANGA DURAI}

AbSTRACT : In this study, we attempted to estimate the influence of household characters on purchasing decision and number of egg consumption by using consumer expenditure survey data collected by National Sample Survey Organization (NSSO), Government of India. Since zero expenditure problem was encountered in the data set, Heckman Sample Selection Model was employed to estimate the purchase probability and demand for egg. Results of the study revealed that prices of egg and fish, per capita income, size of household and having food away from home were the major determinants of purchase probability and consumption of egg. Egg consumption among the poor people was lesser than the middle and higher income people.

KEY WORDS : Egg, Demand, Income, Price, Household, Consumer expenditure

How To Cite This Paper : Umanath, M., Paramasivam, R., Kavitha, V. and Thanga Durai, T. (2016). Determinants of purchase probability and consumption of egg: An evidence from Indian households. Internat. Res. J. Agric. Eco. \& Stat., 7 (1) : 110-115. 